\title{
NSD1 Gene Mutation
}

National Cancer Institute

\section{Source}

National Cancer Institute. NSD1 Gene Mutation. NCI Thesaurus. Code C153267.

A change in the nucleotide sequence of the NSD1 gene. 